\title{
Human impact on organic matter distribution in the Moskva River
}

\author{
Dmitriy Sokolov*, Oxana Erina, Maria Tereshina, and Sergey Chalov \\ Lomonosov Moscow State University, Faculty of Geography, GSP-1, 1 Leninskiye Gory, 119991, \\ Moscow, Russia
}

\begin{abstract}
In 2019, we conducted an integrated study on the Moskva River and its tributaries during the low summer season with a focus on organic matter content $(\mathrm{OM})$ assessment in river waters. The maximum OM content was measured at the river headwaters and related to natural sources. The Mozhaysk Reservoir regulation in the summer had the effect of increased organic load below the dam due to a rise in the allochthonous labile OM. Upstream from the Moscow City, the OM content was relatively low, despite wastewater inflow from several densely populated areas and polluted river inflow. Within the city, organic matter concentration increased by a factor of 1.5 due to an inflow from the Volga River via the Moskva-Volga Canal, whereas the release of treated sewage from the Moscow City wastewater treatment facilities did not have a significant effect. Below the city, the $\mathrm{OM}$ content increased again by a factor of 1.5 due to the inflow of urban and industrial wastewater and polluted tributaries. The observations in the lower reaches of the Moskva River indicate a high degree of anthropogenic euthrophication.
\end{abstract}

\section{Introduction}

The organic matter $(\mathrm{OM})$ content determines the metabolism of freshwater ecosystems [12]. As the global warming causes shifts in the carbon balance, the rivers with high OM content, especially ones with higher labile fraction, contribute to an increase in global $\mathrm{CO}_{2}$ emissions $[3,4]$.

The OM content serves as an important indicator of the river water quality [5]. Because poorly treated sewage may contain large amounts of the OM and can affect the selfpurification capacity of streams $[6,7]$, the determination of the OM content is a mandatory part of the water quality monitoring below releases from wastewater treatment plants. Organic matter also participates in the transport of other pollutants, such as heavy metals $[8,9]$, and can therefore increase overall water toxicity.

In many countries, indirect the indicators of the total organic content are used instead of the organic carbon concentration to monitor the wastewater quality $[10,11]$. The biochemical oxygen demand (BOD) can characterize the labile organic matter content, the true water color (TC) and permanganate index $\left(\mathrm{COD}_{\mathrm{Mn}}\right)$ reflect the quantity of

\footnotetext{
*Corresponding author: Dmitriy.Sokolov@yandex.ru
} 
allochthonous OM, such as humic substances, and the chemical oxygen demand (COD) corresponds well to a total organic matter content.

The Moskva River is a relatively small stream in Central Russia whose natural OM regime is influenced by a number of factors. In its upper reaches, the organic matter balance is affected by dam regulation [12]. The Moskva-Volga Canal, which aids navigation in the middle and lower reaches of the Moskva River, provides an inflow of water with a naturally high humic content. Moreover, the urban sewage from the Moscow City, which contributes to half of the total water flow below the city, contains high amounts of nutrient and organic matter and therefore plays a large part in the Moskva River organic pollution [13-14].

The OM dynamics in the Moskva River basin has mostly been studied in the Moskva's upper reaches because of its importance in the Moscow City water supply. Almost no data on the organic matter of the lower Moskva River and its tributaries below the city have ever been published.

The anthropogenic organic pollution of rivers becomes the most pronounced during low flow periods, when the wastewater is insufficiently diluted by non-polluted water and the ecosystem cannot effectively process the sewage inflow. Because of that, we chose the dry summer period to assess the human impact on the OM content in the Moskva River basin.

\section{Materials and methods}

The fieldwork on the Moskva River and its tributaries was performed on August 6-8, 2019, during a consistent low flow period. It included sampling at 38 sites evenly distributed from source to mouth of the Moskva River and at 18 sites on the tributaries (Fig. 1). Sampling points on the Moskva River were appointed after the confluences with major tributaries and below potential human pollution sources - larger towns, wastewater discharges, etc. In this study we included 12 of the largest Moskva River tributaries (with total length over $30 \mathrm{~km}$ and watershed area over $150 \mathrm{~km}^{2}$ ) and 5 smaller ones (with length of 10-20 km and watershed area below $120 \mathrm{~km}^{2}$ ) that are considered being significantly polluted. The wastewater discharge from the Lyubertsy sewage treatment plant was regarded as one of the smaller tributaries.

In the water chemistry laboratory of the Moscow State University, we determined the COD by dichromate method (ISO 6060:1989), the permanganate index COD $_{\mathrm{Mn}}$ (ISO 8467:1993), water color TC (ISO 7887:2011) and biochemical oxygen demand with incubation period of 5 days $\mathrm{BOD}_{5}$ (ISO 5815-2:2003) in the collected samples. To estimate the proportion of the dissolved organic matter in the total OM content, the COD value was determined twice - before and after $0.45 \mu \mathrm{m}$ membrane filter filtration.

For most of its course, the Moskva River is legally considered an inland fishery. From its source to the city limits, it is also a part of the Moscow City drinking water supply system. Russian technical regulations establish the following guidelines - maximum permissible concentrations (MPC) for the OM content in fisheries and drinking water supply: the $\mathrm{COD}$ value cannot exceed $15 \mathrm{mgO} / \mathrm{L}, \mathrm{BOD}_{5}$ value $-2 \mathrm{mgO}_{2} / \mathrm{L}$; the permanganate index and true water color in centralized water supply systems should not exceed $5 \mathrm{mgO} / \mathrm{L}$ and $20 \mathrm{TCU}$, respectively.

\section{Results and discussion}

The maximum values of COD (150 mgO/L, 10-fold MPC exceedance), $\mathrm{COD}_{\mathrm{Mn}}(80 \mathrm{mgO} / \mathrm{L}$, $16 \mathrm{MPC}$ ) and TC (570 TCU, $28 \mathrm{MPC})$ were measured at the source of the Moskva River, in a small stream flowing from the Starkovsky wetland (Fig. 2, a-c). High OM content here is due to the natural abundance of humic substances. At $7 \mathrm{~km}$ downstream from the source, 
the $\mathrm{OM}$ content decreased by 6-10 times, and then another 1.6-1.8 times at $30 \mathrm{~km}$ downstream, where none of the values increased the MPCs by more than 1.5 -fold. Above the Mozhaysk Dam, the labile OM content as shown by the $\mathrm{BOD}_{5}$ value (Fig. 2, d) exceeded the MPC by 3.6 times at the river source, and was within the limits of 0.7-1.2 $\mathrm{mgO}_{2} / \mathrm{L}(0.3-0.6 \mathrm{MPC})$ in all the other samples from the Moskva River and its tributaries.

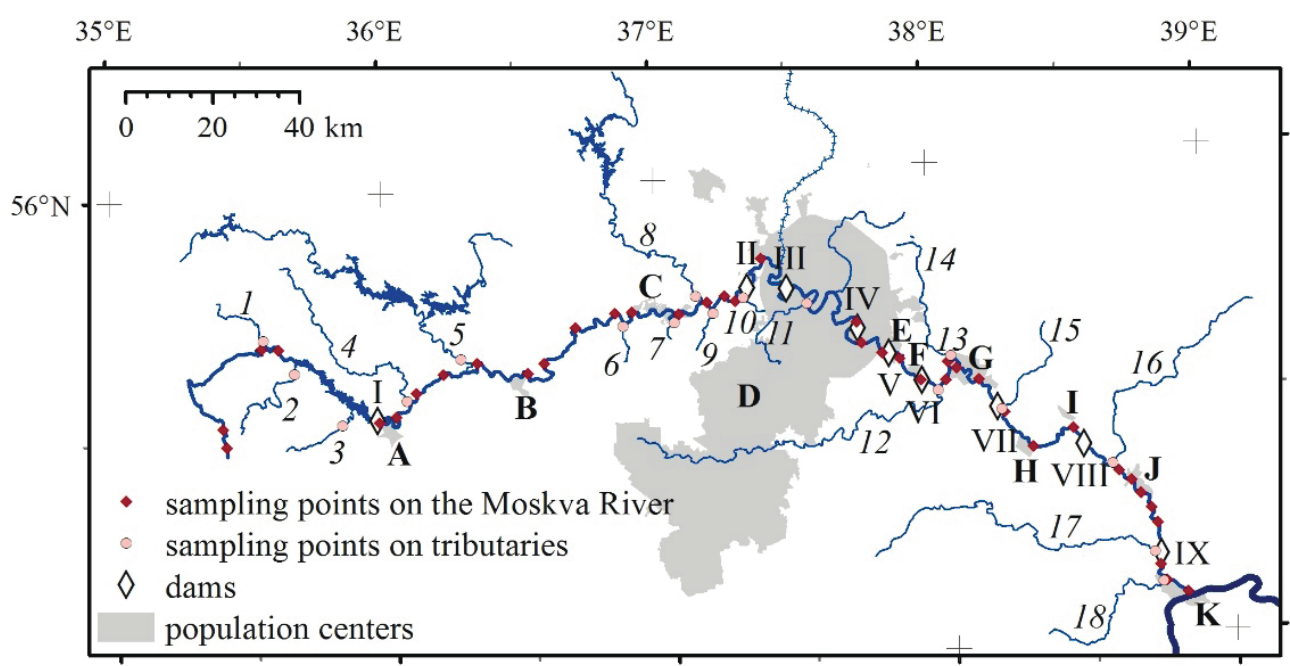

Fig. 1. The Moskva River basin. Water sampling points on the tributaries: 1 - Inoch, 2 - Lusyanka, 3 - Koloch, 4 - Iskona, 5 - Ruza, 6 - Nahavnya, 7 - Vyazemka, 8 - Istra, 9 - Medvenka, 10 Chachenka, 11 - Setun, 12 - Pahra, 13 - discharge from the Lyubertsy sewage treatment plant, 14 Pehorka, 15 - Gzhelka, 16 - Nerskaya, 17 - Severka, 18 - Kolomenka. Population centers: A Mozhaysk, B - Tuchkovo, C - Zvenigorod, D - Moscow, E - Dzerzhinsky, F - Lytkarino, G Zhukovskiy, H - Bronnitsy, I - Beloozerskiy, J - Voskresensk, K - Kolomna. Damsand locks on the Moskva river: I - Mozhaysk, II - Rublyovo, III - Karamyshev, IV - Pererva, V - Trudkommuny, VI - Andreevskoye, VII - Sofyino, VIII - Faustovo, IX - Seversky.

The Mozhaysk Reservoir causes significant shifts in the organic load of the Moskva River [12]. In the summer, when the OM inflow into the reservoir is at its lowest and the labile $\mathrm{OM}$ production is high, the $\mathrm{BOD}_{5}$ value below the dam is 3.5 times higher than in the reservoir's inflows, and $\mathrm{COD}$ and $\mathrm{COD}_{\mathrm{Mn}}$ values are 1.5 times higher. By contrast, the water color below the dam was reduced by $30 \%$, as the reservoirs' OM retention capacity is the strongest towards colored organic matter and may reach $40 \%$ for humic substances [12].

From the Mozhaysk Dam to the Moscow City limit, OM content in the Moskva River varied slightly and exceeded the MPCs by 1.1-1.9 times. The COD value was within the range of 17-24 mgO/L, $\mathrm{COD}_{\mathrm{Mn}}-7-10 \mathrm{mgO} / \mathrm{L}, \mathrm{TC}-22-32 \mathrm{TCU}$ (Fig. 2, $a-c$ ). The human impact was most evident in the labile OM content: the maximum $\mathrm{BOD}_{5}\left(2.6-3.6 \mathrm{mgO}_{2} / \mathrm{L}\right)$ was measured below the urban wastewater discharges and in the densely populated areas of the Moscow City, and the minimum $\left(0.5 \mathrm{mgO}_{2} / \mathrm{L}\right.$, or $\left.0.3 \mathrm{MPC}\right)$ - within a natural reserve (Fig. 2, d). The maximum OM content among the tributaries (1.4-2.5 MPC for COD, 1.21.4 MPC for $\mathrm{BOD}_{5}$ ) was recorded in the Ruza River and in small rivers near the Moscow City (Vyazemka and Medvenka). 


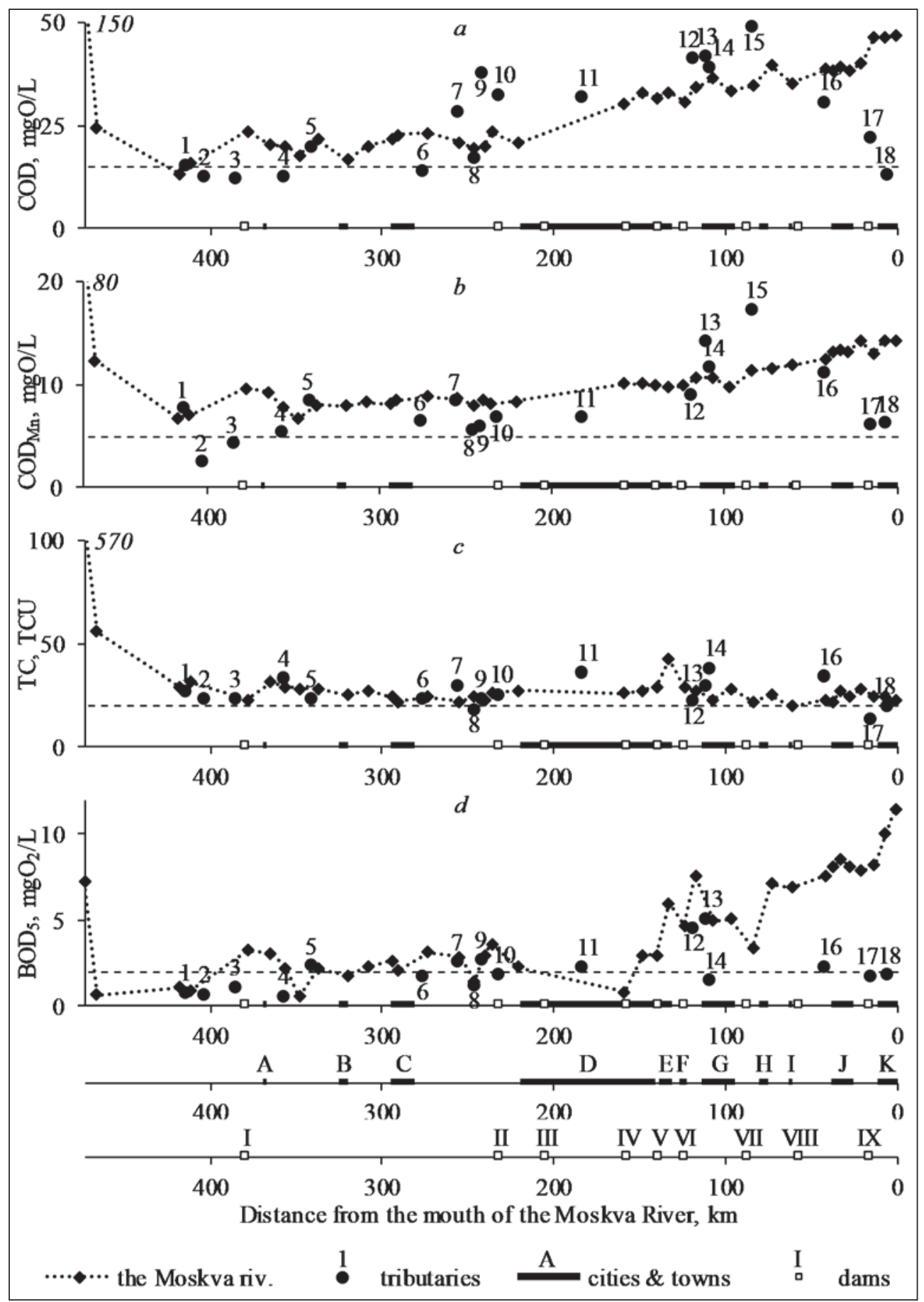

Fig. 2. $\mathrm{COD}(a), \mathrm{COD}_{\mathrm{Mn}}(b), \mathrm{TCU}(c)$, and $\mathrm{BOD}_{5}(d)$ values in the Moskva River and its tributaries in August 2019 (the dashed line represents the MPC value; COD, $\mathrm{COD}_{\mathrm{Mn}}$ and TC values at the Moskva River source are shown outside of their scales and labeled in italics). For identification of the tributaries, towns and dams - see the caption for Fig. 1. 
Within the Moscow City limits, the COD value increased sharply by $1.5-2$ times (from 21 to $33 \mathrm{mgO} / \mathrm{L}$, in filtered samples - from 16 to $30 \mathrm{mgO} / \mathrm{L}$ with a 2-fold decrease in the proportion of particulate organic matter). All the other indexes did not experience a significant change. The MPC exceedance in the city has therefore reached 2 for COD and $\mathrm{COD}_{\mathrm{Mn}}$, and remained at the level of 1.5 for $\mathrm{TC}$ and $\mathrm{BOD}_{5}$. It should be noted that the inflow of the urban wastewater from the Kuryanovo sewage treatment facilities had virtually no effect on the OM content. Therefore, the apparent reason for the COD increase is the inflow of the Volga waters through the Moskva-Volga Canal, which are naturally enriched with OM [12].

From the Moscow City to Bronnitsy, the COD value increased from 30 to $40 \mathrm{mgO} / \mathrm{L}$ (2.6 MPC), and $\mathrm{COD}_{\mathrm{Mn}}$ value increased from 10 to $12 \mathrm{mgO} / \mathrm{L}$ (2.3 MPC), with local peaks in Zhukovsky and Bronnitsy. The $\mathrm{BOD}_{5}$ value ranged from 3.0 to $7.6 \mathrm{mgO}_{2} / \mathrm{L}(1.5-3.8$ MPC), the highest content of labile OM was registered below the discharge from the Dzerzhinsk power station and sewage treatment plant $\left(6.0 \mathrm{mgO}_{2} / \mathrm{L}\right)$, at the mouth of the Pahra river $\left(7.6 \mathrm{mgO}_{2} / \mathrm{L}\right)$, and below the wastewater discharge from Bronnitsy (7.1 $\left.\mathrm{mgO}_{2} / \mathrm{L}\right)$. The true water color from the Moscow City to the river's mouth varied between 20-30 TCU (1.0-1.4 MPC), increasing below wastewater discharges and decreasing in sparsely populated areas. The most polluted tributary in this area (with COD about 50 $\mathrm{mgO} / \mathrm{L}$, or $3.3 \mathrm{MPC}$ ) was the Gzhelka River, which receives the wastewater of Ramenskoye. The Pakhra River and the wastewater from Lyubertsy water treatment facilities also had a high OM content (COD over $40 \mathrm{mgO} / \mathrm{L}, \mathrm{BOD}_{5}$ about $5 \mathrm{mgO}_{2} / \mathrm{L}$ ).

From Bronnitsy to Kolomna, the OM content remained consistently high, with $\mathrm{COD}$ reaching $40 \mathrm{mgO} / \mathrm{L}, \mathrm{COD}_{\mathrm{Mn}}-14 \mathrm{mgO} / \mathrm{L}, \mathrm{BOD}_{5}-6.9-8.6 \mathrm{mgO}_{2} / \mathrm{L}$ with a peak $\mathrm{MPC}$ exceedance of more than 4 below the industrial zone of Voskresensk. In Kolomna, the value of COD increased sharply to $46-47 \mathrm{mgO} / \mathrm{L}$ (more than $3 \mathrm{MPC}$ ), $\mathrm{BOD}_{5}$ - to $10.0-11.5$ $\mathrm{mgO}_{2} / \mathrm{L}$ (5-6 MPC), although the tributaries at this section of the Moskva River had a relatively low OM content (no more than 1.5 MPC for all values).

One of the possible reasons for the high total and labile OM content in the samples taken on August 8 in the lower reaches of the Moskva River is increased phytoplankton production induced by an abundant nutrient input with wastewaters, slow water mixing due to backwater from Faustovo and Seversky dams and the Oka River, and hot weather (after several cold days, the air was warmed up to $25^{\circ} \mathrm{C}$, water - to $20{ }^{\circ} \mathrm{C}$ ). This hypothesis is supported by the fact that the oxygen saturation in the river reached $170 \%$.

\section{Conclusion}

The dynamics of the OM content in the Moskva River remains close to natural conditions only within a small section of the river upstream from the Mozhaysk Reservoir. Along the river course, there is a gradual decrease in the relative proportion of natural humic substances and an increase in the share of labile organics. The labile OM can be supplied into the Moskva by wastewater discharge and inflow of polluted tributaries (direct pollution), but may also be produced by phytoplankton in favorable conditions (anthropogenic eutrophication).

In the summer of 2019, the labile OM content increased 10-20 times (exceeding MPC by 5-6 times) from the upper reaches (excluding the river source) to the mouth of the Moskva River. Permanganate index increased two-fold, water color declined slightly and rarely exceeded 1.5 MPC. The most dramatic change in the OM load was observed within the Moscow City limits, where the OM concentration sharply increased by 1.5 times due to the inflow of the Volga waters via the Moskva-Volga Canal. 
This study was supported by the Russian Geographical Society (project "The Moscow river from the headwaters to the mouth: hydrological and geochemical assessment of ecological state") with regard to the calculations, methods, and data. The influence of the Moscow City on the OM content in the Moskva River was studied with support of the Russian Science Foundation (project no. 19-77-30004)

\section{References}

1. E.H. Stanley, S.M. Powers, N.R. Lottig, I. Buffam, J.T. Crawford, Freshwater Biol., 57, $26(2012)$

2. J.L. Tank, E.J. Rosi-Marshall, N.A. Griffiths, S.A. Entrekin, M.L. Stephen, J.N. Am. Benthol. Soc., 29(1), 118(2010)

3. R.G. Spencer, K.D. Butler, G.R. Aiken, J. Geophys. Res. - Biogeo., 117, G3 (2012)

4. Y.Q. Tian, Q. Yu, A.D. Feig, C. Ye, A. Blunden, Ecol. Eng., 54, 192 (2013)

5. W.R. Abraham, Int. J. Microbiol., 2011, 798292 (2010)

6. T. García-Armisen, Ö. İnceoğlu, N.K. Ouattara, A. Anzil, M.A. Verbanck, N. Brion, P. Servais, PloS one 9(3), e92579 (2014)

7. L.A. de Assis Costa, D.M.M. Pessoa, R. da Silva Carreira, Ecol. Indic., 90, 513 (2018)

8. X. Zheng, L. Yang, Q. Shen, C. Zhou, Ind. Eng. Chem. Res., 58(19), 7929 (2019)

9. G.R. Aiken, H. Hsu-Kim, J.N. Ryan, Environ. Sci. Technol., 45(8), 3196 (2011)

10. S. Li, J. Zhang, G. Mu, H. Ju, R. Wang, D. Li, A.H. Shabbir, Water, 8(9), 399 (2016)

11. J. Xu, G. Jin, Y. Mo, H. Tang, L. Li, Water, 12(1), 246 (2020)

12. D.I. Sokolov, O. Erina, Dissolved Organic Matter (DOM): Properties, Applications and Behavior (Nova Science Publishers, New York, 2017), 81

13. V.A. Razumov, F.I. Tyutyunova, Water Resour., 28(3), 324 (2001)

14. N.M. Shchegol'kova, Water Resour., 34(2), 217 (2007) 